$341.23:[316.32: 004](4-672 € C)$

\author{
ПРАВОВЕ РЕГУЛЮВАННЯ ФУНКЦІОНУВАННЯ \\ ІНФОРМАЦИЙНИХ СИСТЕМ \\ У МЕЖАХ ШЕНГЕНСЬКОГО ПРОСТОРУ
}

\title{
LEGAL REGULATION OF INFORMATION SYSTEMS' FUNCTIONING WITHIN THE SCHENGEN AREA
}

\section{ПРАВОВОЕ РЕГУЛИРОВАНИЕ ФУНКЦИОНИРОВАНИЯ ИНФОРМАЦИОННІХ СИСТЕМ В РАМКАХ ШЕНГЕНСКОГО ПРОСТРАНСТВА}

\author{
Мушак Н. Б.
}

Кандидат юридичних наук, доцент кафедри міжнародного права та порівняльного правознавства Київського університету права НАН України, докторант кафедри європейського і порівняльного права Інституту міжнародних відносин Київського національного університету імені Тараса Шевченка.

E-mail: natali_mushak@ukr.net

\section{Mushak N.}

$\mathrm{PhD}$, Associate Professor, Kyiv University of Law of National Academy of Sciences of Ukraine, doctoral student of the Institute of International Relations of Taras Shevchenko National University of Kyiv.

E-mail: natali_mushak@ukr.net

\section{Мушак Н. Б.}

Кандидат юридических наук, доцент кафедры международного права и сравнительного правоведения Киевского университета права НАН Украины, докторант Института международных отношений Киевского национального университета имени Тараса Шевченко. E-mail: natali_mushak@ukr.net

Анотація. Стаття присвячена дослідженню правового регулювання транскордонних інформаційних систем, які діють у межах Шенгенського простору. Такими інформаџійними системами є Шенгенська інформаџійна система, Візова інформаційна система та Європейська інформаційна система авторизації подорожей. Інформаційні системи надають можливість вільного доступу до бази даних як прикордонним, так і правоохоронним органам держав-учасниць Шенгенського простору, які, в свою чергу, мають змогу швидко та оперативно співпрацювати та взаємодіяти задля підтримки національної безпеки, громадського порядку та ефективної боротьби з організованою злочинністю, перетином кордонів нелегальними іммігрантами, торгівлею наркотиками тощо.

Статтею встановлено, що окрім співробітництва між відповідними компетентними органами держав-учасниць Шенгенського простору інформаційні системи також виступають інструментами реалізачії свободи пересування осіб, сприяючи водночас забезпеченню громадського порядку, начіональної безпеки кожної з європейських держав.

Детально проаналізовано основні завдання та призначення нової Свропейської інформаційної системи авторизаиії подорожей. Зокрема, система стосується тих краӥн, які вже мають укладені угоди про безвізовий режим з Свропейським Союзом. На практиці це означатиме, щзо як і раніме, громадяни "безвізових" країн матимуть змогу подорожувати до держав-учасниць Шенгенського простору без віз, але від них вимагатиметься обов'язкова авторизація через иџю систему перед здійсненням подорожі.

(C) Мушак Н. Б. 2017 
Проаналізовано правові акти Свропейського Союзу, західну та вітчизняну доктрину щуодо функиіонування транскордонних інформаційних систем у межах Шенгенського проcmopy.

Ключові слова: інформачійні системи, Шенгенський простір, Шенгенська інформаиіийна система, Візова інформаційна система, Свропейська інформаційна система авторизачїі подорожей.

Abstract. The article investigates the legal regulation of cross-border information systems that operate within the Schengen area. These information systems are the Schengen Information System, Visa Information System and the European Travel Information and Authorisation System. The information systems provide the opportunity of free access to the database of border and law enforcement authorities of the Schengen area member states. These authorities are able to quick and efficient collaboration as well as in interaction in support of national security, public order and effective fight against organized crime, border-crossing of illegal immigrants, drug trafficking etc.

The article defines that in addition to cooperation between the competent and relevant authorities of the Schengen area member states the information systems are to be the instruments of the freedom of movement of persons, contributing at the same time of public order and national security of each of the European countries.

The article analyses the main tasks and purposes of a new European travel information and authorization system. In particular, the system concerns those countries that have already signed agreements on visa-free regime with the EU. In practice, it means that the citizens of "visa-free" countries will be able to travel to the Schengen area member states without a visa, but they are required to be authorized through this system before the trip.

The research also analyzes the regulations of the European Union, western and national doctrine in respect of the operation of cross-border information systems within the Schengen area.

Key words: information systems, Schengen area, Schengen Information System, Visa Information System, European Travel Information and Authorisation System.

Аннотация. Статья посвящена исследованию правового регулирования трансграничных информационных систем, действующих в рамках Шенгенского пространства. Такими информачионными системами является Шенгенская информационная система, Визовая информационная система и Европейская информационная система авторизации путешествий. Информационные системы предоставляют возможность свободного доступа к базе данных как пограничным, так и правоохранительным органам государств-участников Шенгенского пространства, которые, в свою очередь, могут быстро и оперативно сотрудничать и взаимодействовать для поддержки начиональной безопасности, общественного порядка и эффективной борьбы с организованной преступностью, пересечением грании нелегальными иммигрантами, торговлей наркотиками и тому подобное.

Статьей установлено, что кроме сотрудничества между соответствующими компетентными органами государств-участников Шенгенского пространства информационные системь также выступают инструментами реализации свободы передвижения лии, способствуя одновременно обеспечению общественного порядка, наичональной безопасности каждой из европейских стран.

Детально проанализированы основные задачи и назначение новой Европейской информационной системы авторизации путешествий. В частности, система касается 
тех стран, которые уже имеют заключенные соглашения о безвизовом режиме с Европейским Союзом. На практике, это означает, что по-прежнему граждане «безвизовых» стран смогут путешествовать в страны-участницы Шенгенского пространства без виз, но от них потребуется обязательная авторизация через эту систему перед осуществлением путешествия.

Проанализированы правовые акты Европейского Союза, западную и отечественную доктрину о функиионировании трансграничных информационных систем в рамках Шенгенского пространства.

Ключевые слова: информационные системы, Шенгенское пространство, Шенгенская информационная система, Визовая информационная система, Европейская информационная система авторизаџии путешествий.

Постановка проблеми. Шенгенський простір - це правопорядок, в основі якого лежать спільні цілі та принципи; функціонує спільний договірний та інституційний механізми; діють спільні правові норми, заходи та інструменти, пов'язані із скасуванням контролю на зовнішніх кордонах; гармонізацією умов в ’їду та видачею короткострокових віз; процедурою перетину особами зовнішніх кордонів держав-членів СС; співпрацею судових та поліцейських органів держав-учасниць Шенгенського простору; створенням Шенгенської інформаційної системи, Візової інформаційної системи тощо. На сьогодні Шенгенський простір формують 22 держави-члени СС та чотири асоційовані країни: Швейцарія, Ліхтенштейн, Норвегія та Ісландія.

В рамках Шенгенського простору, всередині якого кордони відкриті, а на зовнішніх кордонах діють єдині правила в 'їзду, питання функціонування транскордонних інформаційних систем є особливо актуальним. Пояснюється це насамперед тим, що такі системи надають можливість вільного доступу до бази даних як прикордонним, так і правоохоронним органам держав-учасниць Шенгенського простору, які, в свою чергу, мають змогу швидко та оперативно співпрацювати та взаємодіяти задля підтримки національної безпеки, громадського порядку та ефективної боротьби з організованою злочинністю.

Мета статті - дослідити правове регулювання функціонування транскордонних інформаційних систем у межах Шенгенського простору; визначити структуру, процедуру та функції інформаційних систем; встановити ефективність їх функціонування на практиці тощо.

Аналіз останніх досліджень та публікацій. Питання аналізу та дослідження дієвості інформаційних систем у межах Шенгенського простору є предметом наукового інтересу як західних, так і вітчизняних вчених. Так, систему правових актів Свросоюзу, які регулюють інформаційні системи, детально досліджено у наукових працях С. Пірса, питання структури та функцій ретельно проаналізовано у працях Дж. Дюмортьє, С. Караньї, Дж. Паркін, Р. Фішера. У свою чергу, в українській науці європейського права лише у працях В. Муравйова та 3. Макарухи приділена увага окремим напрямам співпраці державучасниць Шенгенського простору.

Виклад основного матеріалу дослідження. Серед основних інформаційних систем у межах Шенгенського простору важливе місце відводиться функціонуванню Шенгенської інформаційної системи, Шенгенської інформаційної системи другого покоління, Візової інформаційної системи та Європейської інформаційної системи авторизації подорожей. Основне призначення інформаційних систем полягає в обміні даними між державами-учасницями Шенгенського простору щодо полегшення процедури подання візової заявки громадянами третіх країн, перевірки на зовнішніх кордонах, а також підвищення безпеки європейських країн. Зокрема, завдяки функціонуванню Шенгенської інформа- 
ційної системи (Schengen Information System) (далі - ШІС) правоохоронні органи державучасниць Шенгенського простору співпрацюють у сфері внутрішньої безпеки.

У доктрині права СС побутує думка, згідно з якою Шенгенська інформаційна система становить один із елементів Шенгенської системи щодо охорони кордонів, за допомогою якої відповідні органи держав-учасниць Шенгенського простору мають змогу отримувати необхідну для них інформацію стосовно осіб, яким заборонено перетинати територію держав-членів СС [1, с. 201].

Однак ми вважаємо, що сфера застосування ШІС є значно ширшою. На сьогодні всі європейські митні, прикордонні, правоохоронні та судові органи держав-учасниць Шенгенського простору можуть отримати у цій системі інформацію не лише про зниклих осіб або правопорушників, але й про предмети, зокрема, автомобілі та зброю.

Правові засади функціонування ШІС визначено у Розділі IV (ст. 92-119) Шенгенської конвенції 1990 р. Відповідно до ст. 92 державами-учасницями Шенгенського простору створено спільну Шенгенську інформаційну систему, що включає національну частину, яка знаходиться в розпорядженні кожної держави, а також функцію технічної підтримки.

За допомогою автоматизованої пошукової процедури ШІС органи відповідних держав отримують доступ до інформації стосовно осіб та предметів для здійснення прикордонного контролю та перевірок, поліцейського і митного контролю, здійснення процедури видачі віз, надання дозволів на проживання тощо [2].

Основна мета ШІС полягає у забезпеченні громадського порядку, безпеки, у тому числі державної безпеки, а також у реалізації свободи пересування осіб у межах Шенгенського простору за допомогою інформації, що передається через дану систему (ст. 93 Шенгенської конвенції 1990 р.).

Низка іноземних фахівців у сфері права Свропейського Союзу зазначають, що мета ШІС зводиться лише до координації співробітництва поліцейських органів держав-учасниць Шенгенського простору [3, с. 179].

Однак ми не поділяємо у повній мірі такий підхід. Оскільки, окрім забезпечення громадського порядку та безпеки, Шенгенська інформаційна система виступає також інструментом реалізації свободи пересування осіб, сприяючи водночас зміцненню та поширенню співробітництва між поліцейськими, імміграційними, митними та іншими відповідними компетентними органами держав-учасниць Шенгенського простору. Крім того, запровадження ШІС є однією з основних вимог реалізації положень Шенгенської конвенції 1990 р. Це означає, що жодна країна не може приступити до процесу імплементації Шенгенської конвенції 1990 р. до того часу, допоки не буде запроваджено Шенгенську інформаційну систему на іiі території.

Із набуттям чинності 26 березня 1995 р. Шенгенської конвенції 1990 р. та ліквідацією перевірок на внутрішніх кордонах держав-учасниць Шенгенського простору ШІС вступила в дію.

Загалом, Шенгенська інформаційна система є досить об'ємною та розвиненою інформаційною системою, яка містить відомості про осіб, документи та об'єкти, які перебувають у розшуку. Дана система надає змогу перевірити дані щодо особи або об’єкта, які вводяться в систему, і які дії необхідно вжити у конкретному випадку. Наприклад, завдяки ШІС, відповідні органи прикордонних служб перевіряють чи інформація про особу, щодо якої проводиться перевірка, міститься у базі даних чи ні. У випадку позитивної відповіді (hit), ШІС визначає, які дії повинні бути застосовані уповноваженими органами держав. Серед таких дій є:

а) арешт із метою екстрадиції;

б) відмова у в’їзді особам, які перебувають у розшуку; 
в) відомості про безвісти зниклих осіб;

г) дані про свідків та осіб, яким в рамках процедури кримінального розслідування направлена повістка з вимогою з'явитися в судові органи тощо.

3 метою проведення консультацій між органами держав-учасниць Шенгенського простору доступ до ШІС є постійним, а саме 24 години на добу. Як зазначає Дж. Дюмортьє, такий швидкий та ефективний доступ до бази даних за принципом hit / no hit надає змогу особам уникати зайвих затримок та черг, наприклад, в аеропортах [4, с. 116].

ШІС складається 3:

а) національних систем, які разом формують національну систему (далі - Н-ШІС) та

б) центральної системи технічної підтримки (далі - Ц-ШІС).

Взаємозв'язок між центральною і національною системами здійснюється за допомогою складної інфраструктури, а саме кабельних та інших мереж.

Національні системи (Н-ШІС) функціонують на території кожної з держав-учасниць Шенгенського простору під керівництвом спеціальної установи, якою є офіс Н-ШІС, що знаходиться в структурі міністерства внутрішніх справ чи аналогічної установи відповідної держави. Національна система може містити повну або часткову копію загальної бази даних ШІС.

Кожна з держав несе відповідальність за створення і підтримку власної Н-ШІС. Крім того, держави є відповідальними за достовірність інформації, яка передається до Ц-ШІС. Файли даних всіх Н-ШІС держав є ідентичними, що забезпечується Ц-ШІС. Н-ШІС надає змогу уповноваженим національним органам шукати необхідну інформацію у базі даних ШІС. Компетентні національні органи кожної з держав можуть проводити пошук інформації лише у власній базі даних Н-ШІС, оскільки доступ до Н-ШІС інших держав $є$ неможливим. Основний принцип, на основі якого функціонує ШІС, полягає в тому, що національні системи Н-ШІС кожної з країн не можуть обмінюватися комп'ютеризованою інформацією безпосередньо між собою [5]. Замість цього обмін відбувається лише через Ц-ШІС.

Центральна система (Ц-ШІС) знаходиться у м. Страсбурзі (Франція). Уряд Франції несе відповідальність за дію Ц-ШІС. Однак така відповідальність носить лише формальний характер. Основний обов'язок за функціонування Ц-ШІС покладено на постійну робочу групу, що складається з представників держав-учасниць Шенгенського простору.

У базі ШІС інформація зберігається відповідно до законодавства кожної країни. Наразі у ній знаходяться більше 46 мільйонів записів, що містять наступну інформацію: прізвище та ім'я; дату народження; місце народження; стать; національність; будь-які, що використовуються, псевдоніми; чи озброєна дана людина; чи людина чинить опір (при затриманні) (ст. 94(3) Шенгенської конвенції 1990 р.).

У зв'язку з подальшим розширенням Свропейського Союзу у 2004 р. постало питання про необхідність удосконалення ШІС, яка почала застосовуватися на території Данії, Фінляндії, Швеції, Ісландії та Норвегії з 01 січня 2000 р. Тому, 01 грудня 2000 р. ШІС було модифіковано та технічно оновлено у зв'язку з ухваленням Радою СС Рішення 2000/777/СС [6].

Відповідно до документа положення Шенгенського права почали застосовуватися до Данії, Фінляндії, Швеції, Ісландії та Норвегії, починаючи з 25 березня 2001 р. Саме $з$ цього часу система отримала нову назву - Шенгенська інформаційна система другого покоління (далі - ШІС II). При цьому основна проблема функціонування системи полягала у їі неспроможності у повній мірі обслуговувати більше 18 держав-учасниць Шенгенського простору. Тобто, у випадку приєднання до цієї системи ряду інших європейських країн, 
система не змогла б забезпечити належного рівня охорони персональних даних стосовно громадян третіх країн.

На даний момент Шенгенська інформаційна система використовується Бельгією, Німеччиною, Люксембургом, Нідерландами, Францією, Австрією, Угорщиною, Грецією, Данією, Ісландією, Іспанією, Італією, Латвією, Литвою, Мальтою, Норвегією, Польщею, Португалією, Словаччиною, Словенією, Фінляндією, Чехією, Швецією, Естонією, Великобританією та Швейцарією. Що стосується Північної Ірландії, то країна, користуючись принципом opt-out, вибірково бере участь у положеннях, які стосуються функціонування Шенгенської інформаційної системи. Великобританія приєдналася до ШІС II у березні 2015 р. Відповідно поліція та інші правоохоронні органи країни отримали доступ до бази даних цієї системи.

ШІС II функціонує на основі Рішення Ради СС 2007/533/JНА від 12 червня 2007 р. щодо створення, експлуатації та управління ШІС II [7]. У свою чергу, у Рішенні Комісії EC 2010/261/EU від 04 травня 2010 р. «План безпеки Центральної ШІС II і комунікаційної інфраструктури» передбачено організацію безпеки Центральної ШІС II та іiї комунікаційної інфраструктури, та встановлено план забезпечення їх безпеки [8]. Основна мета полягає у забезпеченні захисту від будь-якої загрози доступу, недоторканності і конфіденційності інформації. Комісія СС несе відповідальність за застосування та контроль над заходами безпеки комунікаційної інфраструктури та Центральної ШІС II протягом перехідного періоду.

Окрім цього, ШІС II містить інформацію про правопорушення, що скоїли громадяни третіх країн, та дані щодо виписаних таким особам штрафів. Наприклад, якщо іноземець скоїв правопорушення на території однієї з держав-учасниць Шенгенського простору, то така інформація заноситься до ШІС II і $є$ доступною при запиті на отримання візи у будьякому посольстві з країн Шенгенського простору. Термін зберігання всіх даних у ШІС II складає 10 років.

Доступом до даних ШІС II користуються спеціально уповноважені співробітники Сврополу та Євроюсту, а також їх помічники. Зазначені органи мають змогу отримувати доступ лише до конкретних даних лише в рамках виконання своїх обов’язків.

Однак при всіх перевагах та позитивних досягненнях ШІС II слід, безумовно, вказати на певні проблеми у іiі функціонуванні. Зокрема, вони пов'язані зі спробами зламати систему з метою отримання необхідної інформації. Так, 18 січня 2014 р. Міністерством внутрішніх справ Німеччини було встановлено, що базу даних ШІС II зламали хакери, які скопіювали майже 1,2 млн файлів [2]. У файлах містилася інформація про осіб, що знаходяться в розшуку, персон нон грата, підроблені документи тощо. Відповідно, такі проблеми вимагають від Європейського Союзу вжити додаткові технічні та правові заходи з метою забезпечення належного захисту майже 46 млн. даних у ШIC II, що, в свою чергу, визначатиме ії ефективне функціонування.

Окрім функціонування ШІС та ШІС II у межах Шенгенського простору діє Візова інформаційна система (Visa Information System (VIS) - (далі - BIC). ВIC надає змогу виявити інформацію про громадян із третіх країн, які подають заявки на отримання шенгенської візи, визначити осіб, що тимчасово або постійно перебувають у межах держав-учасниць Шенгенського простору та виявити порушників візового режиму на їх зовнішніх кордонах.

ВIC функціонує відповідно до Рішення Ради СС 2004/512/СС «Про створення Візової інформаційної системи», ухваленого 08 червня 2004 р. у м. Люксембурзі (Люксембург) [9].

Відповідно до статті 1 документу ВІС є системою обміну візовими даними між державами-членами СС, що уповноважує національні органи держав-членів СС оновлювати 
візові дані та проводити взаємні консультації в електронній формі. ВІС заснована на централізованій основі і складається з центральної системи - Центральної Візової інформаційної системи (Ц-ВІЗ), інтерфейсів у кожній державі-члені СС - Національних інтерфейсів (Н-BI3), що забезпечують зв'язок із відповідними центральними органами держав-членів $\mathrm{CC}$, а також інфраструктури зв'язку Центральної візової інформаційної системи з Національними інтерфейсами держав-членів СС [9].

09 липня 2008 р. у м. Страсбурзі (Франція) Свропейським парламентом та Радою СС було ухвалено Регламент № 767/2008 стосовно системи ВIC та обміну даними щодо короткострокових віз між державами-членами (далі - Регламент ВIC) [10]. На сьогодні Регламент ВIC та Рішення 2004/512/СС «Про створення Візової інформаційної системи» $є$ правовою основою роботи Візової інформаційної системи в цілому.

База даних ВIC містить наступну інформацію про особу (ст. 9): прізвище, прізвище при народженні, ім'я, стать, дата, місце і країна народження; теперішнє громадянство, а також громадянство при народженні особи; вид і кількість проїзних документів, відомості стосовно органу, що видав їх, дату видачі та строк дії; основні маршрути і тривалість передбачуваного перебування; мету поїздки, передбачувані дати в’їзду і виїзду; перша передбачувана межа в 'їзду або транзитний маршрут; місце проживання; відбитки пальців; категорію візи і номер візового стікеру; відомості про сторону, що запрошує дану особу, зокрема, покриття нею витрат під час перебування особи у даній країні. До бази даних ВIC може бути внесено додаткову інформацію щодо заявника. Наприклад, буквено-цифрові дані особи - кількість виданих, відмовлених, анульованих, скасованих або продовжених віз; фотографії; дані про відбитки пальців особи; відомості про осіб, які подорожують із заявником.

Візова інформаційна система підключена до національної системи кожної країни-учасниці Шенгенського простору за допомогою національного інтерфейсу країни. Дані країни створюють національний орган, що підключений до національних інтерфейсів, що забезпечує доступ до ВIC зі сторони відповідних органів. Кожна країна несе відповідальність за розробку, організацію, управління, експлуатацію та технічне обслуговування своєї національної системи; забезпечення безпеки даних до і під час передачі до національного інтерфейсу; організацію доступу уповноваженими співробітниками і компетентними національними органами до системи ВІС покриття витрат, спричинених їх національною системою.

Для полегшення процедури подання візової заявки громадянами третіх країн та перевірки на зовнішніх кордонах держав-учасниць Шенгенського простору 30 листопада 2009 р. Комісія СС ухвалила Рішення № 2010/49 [11], згідно з яким було визначено перші регіони, у яких використання Візової інформаційної системи було розпочато. Так, в країнах Північної Африки, таких як Алжир, Сгипет, Лівія, Мавританія, Марокко і Туніс Візова інформаційна система розпочала свою роботу 11 жовтня 2011 р. Однак окрім зазначених країн, дана система поступово впроваджується і в інших регіонах світу, зокрема на Близькому Сході (Ізраїлі, Йорданії, Лівані і Сиріі), а також у країнах регіону Перської затоки (Афганістані, Бахрейні, Ірані, Іраку, Кувейті, Оману, Катарі, Саудівській Аравії, Об’єднаних Арабських Еміратах) та ін.

323 червня 2015 р. згідно з Рішенням Комісії СС Візова інформаційна система почала діяти у країнах Східного партнерства, в тому числі, на території України [12]. Наприкінці листопада 2015 р. всі консульства держав-учасниць Шенгенського простору приєдналися до системи ВIC.

Фактично із дати запровадження ВIC на території третіх країн їх громадяни, що подали заявку на отримання шенгенської візи, проходитимуть процедуру дактилоскопії, 
тобто мають здавати відбитки пальців. Що ж стосується шенгенських віз, отриманих до запуску BIC на території третіх країн, то такі візи залишатимуться дійсними до вказаного в них терміну.

На практиці суть процедури дактилоскопії полягає в тому, що заявники на отримання шенгенської візи повинні з'явитися особисто в консульство або візовий центр, щоб надати свої біометричні дані - відбитки пальців та цифрову фотографію. Така процедура стосується, зокрема, заявок на короткострокові шенгенська візи терміном 90 днів протягом 180 днів. Щодо заяв на отримання шенгенської візи протягом наступних 5 років, а саме після подання заяви, коли заявник здавав відбитки пальців, відбитки пальців заявника копіюватимуться з інформації, яка міститься в системі ВІС. Це означає, що відбитки пальців надаються на період 5 років і ці відбитки будуть дійсними для будь-якої подальшої заявки на отримання шенгенської візи протягом 5-річного періоду. Прикладом є подання заявок на довготривалу багаторазову візу. В окремих випадках, коли $є$ необхідність ідентифікувати заявника, то консульський відділ може взяти відбитки пальців також і в період до 5 років.

Виключення із зобов'язань надати відбитки пальців стосуються дітей, молодших 12 років; осіб, у яких фізично неможливо взяти відбитки пальців; глав держав та членів державних урядів, а також членів їх офіційних делегацій та їх чоловіків/дружин, якщо вони подорожують з офіційними цілями.

Загалом передбачається, що у ВІС будуть знаходитися дані про приблизно 80 мільйонів осіб. Тому, на наш погляд, ВIC слід розглядати як частину загальної тенденції в практиці видачі віз Європейським Союзом країнам світу, яка, за умови iï ефективного функціонування, стане найбільшою біометричною базою даних у світі.

У майбутньому ВIC також може містити інформацію про пасажирів авіарейсів, що прибувають на територію держав Шенгену. Ця обставина, вочевидь, буде залежати від ефективного функціонування ВIC, розвитку їі технічної інфраструктури тощо.

Для більш ефективного управління кордонами держав-учасниць Шенгенського простору та покращення внутрішньої безпеки як самих держав, так і їх громадян, 16 листопада 2016 р. у м. Брюсселі Комісія СС оприлюднила свої пропозиції щодо створення у майбутньому нової Європейської інформаційної системи авторизації подорожей (European Travel Information and Authorisation System (ETIAS) - Свропейська інформаційна система авторизації подорожей (далі - СІСАП) [13]. Така система буде стосуватися тих країн, які вже мають укладені угоди про безвізовий режим з Свропейським Союзом. На практиці, це означатиме, що як і раніше, громадяни «безвізових» країн матимуть змогу подорожувати до держав-учасниць Шенгенського простору без віз, але від них вимагатиметься обов'язкова авторизація через цю систему перед здійсненням подорожі.

Основним завданням СІСАП $є$ ідентифікація будь-яких ризиків, що можуть нести відвідувачі з третіх «безвізових» країн, які в’їздитимуть на територію Шенгенського простору. Для видачі авторизації на подорож або відхилення заявки система проводитиме відповідні перевірки.

Комісією СС передбачено, що система розпочне працювати з 01 січня 2020 р. Як і кожна інформаційна система, СІСАП має свою структуру. Зокрема, СІСАП буде складатися з Інформаційної системи, центрального та національних офісів. До Інформаційної системи входитиме Центральна система, яка й прийматиме та оброблятиме заявки на надання дозволів на авторизацію. Центральний офіс ЄІСАП буде створено в рамках Європейської прикордонної і берегової служби та буде її частиною. Так само працюватимуть національні офіси, створені у кожній з держав-учасниць Шенгенського простору. Саме вони нестимуть основну відповідальність за проведення оцінок ризику та ухвалення 
рішення щодо заявок, відхилених під час автоматизованого процесу, а також надання заявникам інформації щодо процедури апеляції [13].

Разом із структурою ЄІСАП передбачена відповідна процедура подачі заявки. Зокрема, громадяни з "безвізових" країн повинні будуть подати он-лайн заявку через вебсайт СІСАП або через мобільний додаток на телефоні. Заповнення заявки забиратиме не більше 10 хвилин і не потребуватиме надання жодних документів, окрім паспорту або його аналогу, тобто проїзного документу. У разі неспроможності людини подати заявку, зокрема, через вік, рівень письменності, доступ до Інтернету або недостатнє знайомство 3 новими технологіями замість неї це може зробити третя особа.

Рішення щодо заявки направлятиметься аплікантам на електронну пошту з авторизацією або обгрунтуванням відмови. Авторизація подорожі, тобто в 'їзд на територію Шенгенського простору, триватиме 5 років або до завершення чинності проїзного документа, наприклад, паспорту.

Перед посадкою в літак або на корабель, а також в автобус у разі транспортування груп перевізники повинні перевірити статус проїзних документів, необхідних для в ’їзду на територію Шенгенського простору - включно з наявністю у громадянина чинної авторизації системою ЄІСАП.

Після прибуття на зовнішні кордони території будь-якої з держав-учасниць Шенгенського простору прикордонники зчитуватимуть електронним способом дані проїзного документа, надсилаючи таким чином запит до різних баз даних, які передбачені Шенгенським прикордонним кодексом. Запит подається також і до самої системи СІСАП, як правило, у випадку безвізових країн. За відсутності чинної авторизації СІСАП прикордонники мають право відмовити у в’їзді та зробити відповідний запис про громадянина [13].

У тих випадках, коли особа отримує відмову від авторизації подорожі від СІСАП, заявник завжди матиме право на апеляцію. Апеляцію потрібно буде подавати в тій державіучасниці Шенгенського простору, яка ухвалила рішення щодо відмови, а також керуючись iï національним законодавством.

Також Комісією СС передбачено формування так званого списку особливого контролю СІСАП. Даний список буде створений та управлятиметься Сврополом. У списку будуть дані щодо осіб, які підозрюються у скоєнні кримінальних злочинів або щодо яких $\epsilon$ факти або серйозні підстави у підозрах щодо можливого майбутнього скоєння таких злочинів.

Список особливого контролю буде створено на основі:

а) списку ООН щодо військових злочинців;

б) інформації, яка стосується терористичних злочинів або інших серйозних кримінальних злочинів, наданої державами-членами СС;

в) інформації щодо терористичних злочинів або інших серйозних кримінальних злочинів, отриманих у межах міжнародного співробітництва[13].

По-суті, передбачена у майбутньому СІСАП покликана сприяти полегшенню процедури перевірок національними прикордонними органами держав-учасниць Шенгенського простору на їх зовнішніх кордонах, забезпечуючи при цьому скоординовану оцінку ризиків від громадян «безвізових» країн. В результаті, це суттєво зменшить кількість відмов у в 'їді на самих зовнішніх кордонах держав-учасниць Шенгенського простору.

Висновки. Діючі інформаційні системи такі, як ШІС, ШІС II та ВIC надають можливість вільного доступу до бази даних як прикордонним, так і правоохоронним органам держав-учасниць Шенгенського простору, які, в свою чергу, мають змогу швидко та оперативно співпрацювати та взаємодіяти задля підтримки національної безпеки, громадсь- 
кого порядку та ефективної боротьби з організованою злочинністю, перетином кордонів нелегальними іммігрантами, торгівлею наркотиками тощо.

Окрім співробітництва між відповідними компетентними органами держав-учасниць Шенгенського простору, інформаційні системи також виступають інструментами реалізації свободи пересування осіб, сприяючи водночас забезпеченню громадського порядку, національної безпеки кожної з європейських держав.

Однак в умовах масштабної імміграційної кризи у Європі, що є ключовим викликом для більшості європейських країн, зазначені інформаційні систем поки що себе не виправдовують.

\section{Список використаних джерел}

1. Peers S. EU Justice and Home Affairs Law / Steve Peers. $-3^{\text {rd }}$ ed. - Oxford: Oxford University Press, 2011. - 983 p.

2. Fisher R. The Europeanization of Migration policy. The Schengen Acquis between the Priorities of Legal Harmonization and Fragmentation / Robert Fisher. - Peter Lang: Internationaler Verlag der Wissenschaften, 2016. - $321 \mathrm{p}$.

3. Karanja S. Transparency and Proportionality in the Schengen Information System and Border Control Cooperation / Stephen Kabera Karanja. - Leiden, Boston: Martinus Nijhoff Publishers, 2008. - 459 p.

4. Dumortie J. Recent Developments in Data Privacy Law / Jos Dumortie. - Leuven: Leuven university press, $1992 .-217 \mathrm{p}$.

5. Commission Decision 2008/333/ JHA of 4 March 2008 adopting the SIRENE Manual and other implementing measures for the second generation Schengen Information System (SIS II) [Електронний ресурс]. - Режим доступу: http://eur-lex.europa.eu/legalcontent/EN/TXT/?uri=celex:32008D0333

6. Council Decision of 1 December 2000 on the application of the Schengen acquis in Denmark, Finland and Sweden, and in Iceland and Norway (2000/777/EC) [Електронний ресурс]. - Режим доступу: http://eur-lex.europa.eu/legal-content/EN/ALL/?uri=CELEX\% 3A32000D0777.

7. Council Decision 2007/533/JHA of 12 June 2007 on the establishment, operation and use of the second generation Schengen Information System (SIS II) [Електронний ресурс] // Official Journal of the European Union, L 205, 7.8.2007. - Режим доступу: http://eurlex.europa.eu/legal-content/EN/TXT/?uri=uriserv:OJ.C_.2014.430.01.0001.01.ENG.

8. Council Decision 2008/615/JHA of 23 June 2008 on the stepping up of cross-border cooperation, particularly in combating terrorism and cross-border crime [Електронний ресурс] // Official Journal of the European Union, L 210/1. - Режим доступу: http://eur-lex.europa.eu/LexUriServ/LexUriServ.do?uri=OJ:L:2008:210:0001:0011:EN:PDF.

9. Council Decision of 8 June 2004 establishing the Visa Information System (VIS) (2004/512/EC) [Електронний ресурс] // Official Journal of the European Union. - L 213/5, 15.6.2004. - Режим доступу: http://eur-lex.europa.eu/legal-content/EN/TXT/?uri=CELEX: $32004 \mathrm{D} 0512$.

10. Regulation (EC) No 767/2008 of the European Parliament and of the Council of 9 July 2008 concerning the Visa Information System (VIS) and the exchange of data between Member States on short-stay visas (VIS Regulation), 13.8.2008 [Електронний ресурс] // Official Journal of the European Union, L 218/60. - Режим доступу : http://eur-lex.europa.eu/LexUriServ/LexUriServ.do?uri=OJ:L:2008:218:0060:0081:EN:PDF.

11. Commission Decision 2010/260/EU of 4 May 2010 on the Security Plan for the operation of the Visa Information System [Електронний ресурс]. - Режим доступу: http://eur- 
lex.europa.eu/legal-content/EN/ALL/;ELX_SESSIONID=kNTyJDJd3LmjTppL7kMlbYCKR0srkzVRy2S7MmTzsnwbdLJJj23N!1535445908?uri=CELEX:32010D0260.

12. Commission Decision EU on Visa Information System launched in the Eastern Partnership countries, including Ukraine on 23 June 23, 2015 [Електронний ресурс]. - Режим доступу: https://eeas.europa.eu/sites/eeas/files/enp-regional-report-eastern_partnership_en. pdf.

13. European Commission.Press release. Security Union: Commission proposes a European Travel Information and Authorisation System, Brussels, 16 November 2016. [Електронний pecypc]. - Режим доступу: http://europa.eu/rapid/press-release_IP-16-3674_en.htm.

\section{References}

1. Peers S. EU Justice and Home Affairs Law / Steve Peers. - 3r $\mathrm{r}^{\mathrm{d}}$ ed. - Oxford: Oxford University Press, 2011. - 983 p.

2. Fisher R. The Europeanization of Migration policy. The Schengen Acquis between the Priorities of Legal Harmonization and Fragmentation / Robert Fisher. - Peter Lang: Internationaler Verlag der Wissenschaften, 2016. - $321 \mathrm{p}$.

3. Karanja S. Transparency and Proportionality in the Schengen Information System and Border Control Cooperation / Stephen Kabera Karanja. - Leiden, Boston: Martinus Nijhoff Publishers, 2008. $-459 \mathrm{p}$.

4. Dumortie J. Recent Developments in Data Privacy Law / Jos Dumortie. - Leuven: Leuven university press, 1992. $-217 \mathrm{p}$.

5. Commission Decision 2008/333 / JHA of 4 March 2008 adopting the SIRENE Manual and other implementing measures for the second generation Schengen Information System (SIS II). Available at: http://eur-lex.europa.eu/legal-content/EN/TXT/?uri=celex:32008D0333.

6. Council Decision of 1 December 2000 on the application of the Schengen acquis in Denmark, Finland and Sweden, and in Iceland and Norway (2000/777 / EC). Available at: http://eur-lex.europa.eu/legal-content/EN/ALL/?uri=CELEX\%3A32000D0777.

7. Council Decision 2007/533 / JHA of 12 June 2007 on the establishment, operation and use of the second generation Schengen Information System (SIS II) // Official Journal of the European Union, L 205, 08.07.2007. Available at: http://eur-lex.europa.eu/legalcontent/EN/TXT/?uri=uriserv:OJ.C_.2014.430.01.0001.01.ENG.

8. Council Decision 2008/615 / JHA of 23 June 2008 on the stepping up of cross-border cooperation, particularly in combating terrorism and cross-border crime // Official Journal of the European Union, L 210/1. Available at: http://eur-lex.europa.eu/LexUriServ/LexUriServ.do?uri=OJ:L:2008:210:0001:0011:EN:PDF

9. Council Decision of 8 June 2004 establishing the Visa Information System (VIS) (2004/512 / EC). Official Journal of the European Union. L 213/5, 15.6.2004. Available at: http://eurlex.europa.eu/legal-content/EN/TXT/?uri=CELEX:32004D0512.

10. Regulation (EC) No 767/2008 of the European Parliament and of the Council of 9 July 2008 concerning the Visa Information System (VIS) and the exchange of data between Member States on short-stay visas (VIS Regulation), 13.8. 2008 // Official Journal of the European Union, L 218/60. Available at: http://eur-lex.europa.eu/LexUriServ/LexUriServ.do?uri= OJ:L:2008:218:0060:0081:EN:PDF

11. Commission Decision 2010/260 / EU of 4 May 2010 on the Security Plan for the operation of the Visa Information System. Available at: http://eur-lex.europa.eu/legal-content/ EN/ ALL/;ELX_SESSIONID=kNTyJDJd3LmjTppL7kMlbYCKR0srkzVRy2S7MmTzsnwbdLJJj23N!1535445908?uri=CELEX:32010D0260. 
12. Commission Decision EU on Visa Information System launched in the Eastern Partnership countries, including Ukraine on 23 June 23, 2015. - Available at: https://eeas.europa.eu/ sites/eeas/files/enp-regional-report-eastern_partnership_en.pdf.

13. European Commission.Press release. Security Union: Commission proposes a European Travel Information and Authorisation System, Brussels, 16 November 2016. Available at: http: //europa.eu/rapid/press-release_IP-16-3674_en.htm. 